\title{
NATURAL AND CULTURAL LAYERS OF COMMUNICATING SELVES IN THE DISCURSIVE BECOMING OF LANGUAGE
}

\author{
ZDZISŁAW WĄSIK
}

\section{Introduction}

The subject matter of this chapter constitutes an evolutional approach to individual/collective dimensions of language as a property of its speakers/learners viewed from the perspective of its discursive becoming in ecologically determined collectivities through transgenerational transmission of inborn speech faculties and conventionally established verbal signs. Therefore, it will start with an introduction into the observable and inferable modes in which language exists through: (1) externalized speech products, (2) internalized thought products, (3) concrete processes of articulation and audition, (4) mental aptitudes of sign-creation and sign-interpretation, (5), relationships between verbal signs, their meaning, and use, (6) mental associations between verbal signs, (7) observable links between interpersonal collectivities, (8) assumable links between intersubjective collectivities, (9) physiological and intellectual endowments of human individuals, and (10) genetic codes transmitted in the evolution of human species.

In the next point of discussion, a synchronic view of language as a system of signs, known from Ferdinand de Saussure's lectures of 1916 (Cours de linguistique générale), will be juxtaposed with two diachronic conceptions, pertaining to the kinship relationships among languages according to August Schleicher's theory of genealogical tree published in 1850 (Die Sprachen Europas in systematischer Über- 
sicht), and a wave theory of Johannes Schmidt from 1872 (Verwandschaftsverhältnisse der indogermanischen Sprachen). Against the background of divergent evolutionism and convergent diffusionism, stating that languages have a mixed character while splitting up both into new branches, and while influencing each other through the dissemination of changes, this paper, aiming at the explanation of language variability, will investigate the applicative value of the metaphor of rhizome proposed by Gilles Deleuze and Félix Guattari in 1976 (Rhizome) along with the metaphor of assemblage created as a parallel term in 1980 (Mille Plateaux).

In keeping distance to original definitions of terms, the author will understand the notion of rhizome as a conflation, or a set of binary relations, formed by multiplicity of interconnected points, or positions; whereas the notion of assemblage, he will specify as an aggregation, or arrangement, of any kinds of heterogeneous things and states of affairs, being thematically concatenated with human expressivity manifested in the intentional production and utilization of verbal signs, referring to virtual, or actual, things and states of affairs, which form the signified and communicated reality of everyday life.

As regards the speaker-centered view of the becoming of a given language, the question will be posed how it comes into being due to its discursive realization through collective assemblages of enunciations. Accordingly, discourse will be referred to expressions/utterances that link communicating individuals taking part in group interactions as physical persons and psychical subjects into interpersonal and intersubjective collectivities when they create and interpret the meanings embodied in material meaning-bearers.

The rhizomatic layers of discourses are seen here as potential owing to an innate speech faculty localized in the genetically specialized neuronal centers of human brains to communicate by using the verbal means of signification through the implementation of certain physiological techniques. Such layers might have emerged as a result of evolutionary adaptations of animal/human organisms to their natural and artificial surroundings through the extension of their communicational abilities preexisting in their genetic memory.

\section{Observable and inferable existence modes of language}

On account of concrete and mental, static and dynamic, substantial and relational manifestations of language as a property of human beings, the object of linguistic study, reconstituted in agreement with the principles of hard-science linguistics by Victor Huse Yngve (From Grammar to Science), may be specified in terms of at least one of six separate existence modes (cf. Wąsik, Epistemological Perspectives on Linguistic Semiotics: 35, and From Grammar to Discourse: 84). 
(1) Language manifests itself in socially accepted patterns of vocal sound waves, which are articulated by speakers and segmented by hearers as the verbal means of individual signification and interindividual communication;

(2) Language sustains itself in the consciousness of speakers/hearers as the mental equivalents of vocal sound waves, which are processed and interpreted as verbal means of individual signification and interindividual communication;

(3) Language recurs in the concrete speaking and hearing activities of individuals who possess physiological endowments for the production and reception of vocal sound waves as the significative means of interindividual communication;

(4) Language endures in the mental sign-processing and sign-interpreting activities of individuals who possess communicational abilities, which allow them to create and recognize vocal sound waves, and their surrogates, as significative means being distinguishable from each other, grammatically correct, semantically meaningful and pragmatically appropriate to respective contexts and situations;

(5) Language is deducible from the socially abstracted networks of relational values of significative means, which are externalized by individual communicators in their concrete speaking and hearing activities;

(6) Language is assumable from the networks of associations between mental equivalents of significative means and their relational values, which are internalized by individual communicators in their sign-processing and signinterpreting activities.

It has to be noticed that all above enumerated six existence modes of language constitute intra-organismic and extra-organismic properties of communicating individuals. In opposition to speech processes, thoughts or networks of associations, which depend upon the physiological and mental capabilities or competencies of individual communicators, only the sets of externalized patterns of verbal products, as well as their relational properties, become independent from the will of particular members of certain collectivities when they function as a means of social communication.

But in the real world, language as a property of collectivity does not constitute a set of empirical data. It may be only assumed as a theoretical construct consisting of the interindividual means and contents of communication that are typified from observable changes in individuals when they are engaged in communicating activities. What can concretely be singled out are no more than referential behaviors of communicators, and their interpretational practices have to be mentally inferred from the shared knowledge of communication participants (cf. Wąsik, From Grammar to Discourse: 85-86). 
Thus, in the physical dimension, communicating individuals are linked with other each interpersonally other through sound waves and energy flow carried out in their sending and receiving activities, and in the logical dimension, intersubjective links come into being through the mutual understanding of people when communicating individuals negotiate and confirm the meaning of verbal means through interpretative practices and referential behavior on the basis of internally concluded commonalities of experience or knowledge about the same domain of reference.

Considering the role of language in the formation of interpersonal collectivities of those who speak and listen to each other and intersubjective collectivities of those who communicate with and understand each other, one can distinguish on the basis of observable and concluded similarities in their referential behavior and their interpretational activities, two additional existence modes of language where: In the first dimension, communicating individuals are linked externally by sound waves and energy flow, and in the second, they are united internally by commonalities of experience or knowledge about the same domain of reference.

(7) Language unites people in concretely observable dynamic interactions when the communicating individuals produce, emit, perceive and receive meaning bearers in the form of sound waves and their surrogate codes through a respective physical channel;

(8) Language can be deduced from the intersubjective linkages that occur between individual communication participants when they understand or interpret received meaning bearers in the same way, referring them to the common extralingual reality known to each other separately.

Apart from the interpersonal links related to the use of language that come into being through the exchange of energy flow being sent and received and the intersubjective domain of reference being inferred by communication participants, there are also inter-organismic links to be taken into consideration, namely the linguistic faculties inherited genetically.

Therefore, alluding to the ascertainments of biological anthropologists one is entitled to assume that language exists also in the generational memory of organisms in form of cultural memes. Worth mentioning is a hypothesis of Edward Sapir and Benjamin Lee Whorf that the perception of extralingual reality is determined by the structure a given language (cf. Whorf Language, Thought, and Reality).

To be exposed is also the claim about the innateness of language resulting from the genotype-phenotype interplay in the genetic code of organisms suggested by Marc D. Hauser, Noam Avram Chomsky and W. Tecumseh Fitch ("The Faculty of Language"), and the presence of primitive patterns in the lingua mentalis, advocated by Anna Wierzbicka (Semantic Primitives and Lingua Mentalis). These conceptions allow formulating a statement about additional two existence modes of language.

(9) Language is possible due to the innate speech faculty localized in genetically specialized neuronal centers of human brains to communicate by 
using vocal systems of verbal means with threefold duality patterns structure and sequential segmentation while implementing complex physiological techniques of articulation and audition.

(10) Language has emerged as a result of evolutionary changes of animal organisms adapting to their natural and artificial surroundings through the extension of their communicative abilities preexisting in their genetic memory as a set of primitive and more developed verbal means (cf. Wąsik, From Grammar to Discourse: 86).

\section{Languages as assemblages of enunciation in natural and cultural reality}

\subsection{Assemblage theory in Gilles Deleuze and Félix Guattari's works}

The subject matter of this subpart constitutes the existential modes of assemblages considered in terms of how they are formed as semiotic objects in the environments of animals and humans. The term assemblage known from the English translations and very often misinterpreted will be explained in relation to the original French term agencement, which means an arrangement of concrete elements and relational aspects. [cf. Gilles Deleuze's and Félix Guattari's discussion of the relationships between an assemblage as, on the one hand, "a machinic assemblage of bodies, of actions and passions, an intermingling of bodies reacting to one another", and, on the other, "a collective assemblage of enunciation, of acts and statements, of incorporeal transformations attributed to bodies" (Deleuze and Guattari, A Thousand Plateaus, 2005/1987: 88)].

When Deleuze asks "What is an assemblage?" he answers that it is "a multiplicity which is made up of heterogeneous terms and which establishes liaisons, relations between them", stressing that its "only unity is that of a co-functioning ... It is never filiations which are important, but alliances, alloys; these are not successions, lines of descent, but contagions, epidemics, the wind" (Deleuze and Parnet, Dialogues II, 2002: 69).

What is an assemblage? It is a multiplicity which is made up of many heterogeneous terms and which establishes liaisons, relations between them, across ages, sexes and reigns - different natures. Thus, the assemblage's only unity is that of cofunctioning: it is symbiosis, a "sympathy". It is never filiations which are important, but alliances, alloys; these are not successions, lines of descent, but contagions, epidemics, the wind. (Dialogues II: 69)

First, in an assemblage there are, as it were, two faces, or at least two heads. There are states of things, states of bodies (bodies interpenetrate, mix together, transmit affects to one another); but also statements, regimes of statements: signs are 
organized in a new way, new formulations appear, a new style for new gestures (the emblems which individualize the knight, the formulas of oaths, the system of "declarations", even of love, etc.) (Dialogues II: 70-71]):

Only one side of the assemblage has to do with enunciation or formalizes expression; on its other side, inseparable from the first, it formalizes contents, it is a machinic assemblage or an assemblage of bodies. Now contents are not 'signifieds' dependent upon a signifier in any way, nor are they 'objects' in any kind of relation of causality with the subject. They have their own formalization and have no relation of symbolic correspondence or linear causality with the form of expression: the two forms are in reciprocal presupposition, and they can be abstracted from each other only in a very relative way because they are two sides of a single assemblage. (Deleuze and Guattari, A Thousand Plateaus, 2005: 140-141)

Compare the English translated from French originals quotations, in which assemblage is treated as a liaison of heterogeneous objects:

Taking the feudal assemblage as an example, we would have to consider the interminglings of bodies defining feudalism: the body of the earth and the social body; the body of the overlord, vassal, and serf; the body of the knight and the horse and their new relation to the stirrup; the weapons and tools assuring a symbiosis of bodies a whole machinic assemblage. (A Thousand Plateaus: 89) ${ }^{1}$

We would also have to consider statements, expressions, the juridical regime of heraldry, all of the incorporeal transformations, in particular, oaths and their variables (the oath of obedience, but also the oath of love, etc.): the collective assemblage of enunciation. On the other axis, we would have to consider the feudal territorialities and reterritorializations, and at the same time the line of deterritorialization that carries away both the knight and his mount, statements and acts. (A Thousand Plateaus: 89)

We must therefore arrive at something in the assemblage itself that is still more profound than these sides and can account for both of the forms in presupposition, forms of expression or regimes of signs (semiotic systems) and forms of content or regimes of bodies (physical systems). This is what we call the abstract machine, which constitutes and conjugates all of the assemblage's cutting edges of deterritorialization. (A Thousand Plateaus: $140-141$ )

What is more Assemblages are specified as sets of enunciations and bodies:

The assemblage has two poles or vectors: one vector is oriented toward the strata, upon which it distributes territorialities, relative deterritorializations, and reterritorializations;

\footnotetext{
1 "Un exemple, l'agencement féodal. On considérer a les mélanges de corps qui définissent la féodalité : le corps de la terre et le corps social, les corps du suzerain, du vassal et du serf, le corps du chevalier et celui du cheval, le nouveau rapport dans lequel ils entrent avec l'étrier, les armes et les outils qui assurent les symbioses de corps - c'est tout un agencement machinique." (Deleuze \& Guattari, Mille Plateaux: 112).
} 
the other is oriented toward the plane of consistency or destratification, upon which it conjugates processes of deterritorialization, carrying them to the absolute of the earth. It is along its stratic vector that the assemblage differentiates a form of expression (from the standpoint of which it appears as a collective assemblage of enunciation) from a form of content (from the standpoint of which it appears as a machinic assemblage of bodies); it fits one form to the other, one manifestation to the other, placing them in reciprocal presupposition. But along its diagrammatic or destratified vector, it no longer has two sides; all it retains are traits of expression and content from which it extracts degrees of deterritorialization that add together and cutting edges that conjugate. (A Thousand Plateaus: 145$)$.

Furthermore, one has to bear in mind the territorial differentiation of enunciative assemblages:

Taking the feudal assemblage as an example, we would have to consider the interminglings of bodies defining feudalism: the body of the earth and the social body; the body of the overlord, vassal, and serf; the body of the knight and the horse and their new relation to the stirrup; the weapons and tools assuring a symbiosis of bodies a whole machinic assemblage. We would also have to consider statements, expressions, the juridical regime of heraldry, all of the incorporeal transformations, in particular, oaths and their variables (the oath of obedience, but also the oath of love, etc.): the collective assemblage of enunciation. On the other axis, we would have to consider the feudal territorialities and reterritorializations, and at the same time the line of deterritorialization that carries away both the knight and his mount, statements and acts. ( $A$ Thousand Plateaus: 89].

\subsection{Understanding the language as an assemblage of enunciation}

In interdisciplinary studies, scientists collect various linguistic data, aiming to support those scientific disciplines, the main object of which belongs to functional environments of languages. As an alternative for strictly linguistic studies, the subject matter of which was language in itself, practitioners of language sciences switch their interest sphere to studies conducted from a perspective of neighboring disciplines.

Linguists exhibiting the social and abstract character of language usually defined it either as (1) the set of mental signs composed of concepts and sound patterns that are shared by all members of a particular speech community, as postulated by Ferdinand de Saussure (Cours de linguistique générale), or (2) the set of concrete types of verbal means of signification that are used for communicating about the extralinguistic reality, following the functionalist principles of Leon Zawadowski (Lingwistyczna teoria języka) and Karl Ludwig Bühler (Sprachtheorie).

In the approaches of isolationists, natural languages were reduced to "stages" and stages identified with "systems". Integrationists, in turn, postulated to investi- 
gate actual speakers, as they cooperate communicatively and interactively with other members of social groupings, such as inter-individual, public and mass aggregations of local or global, national or international communities connected by blood kinship or ethnic descent, common profession or confession, and shared means of signification or cognition.

In such an integrational and interdisciplinary context, the pragmatic position of Gilles Deleuze and Félix Guattari (A Thousand Plateaus, 2005: 89) to language as a "collective assemblage of enunciation" is worth exposing as fruitful and innovative.

The notion of language as an assemblage of enunciation is placed in the context of social discourses. Furthermore it is also discussed in relation to constitutive elements of particular realization of speech acts composed of signs.

\section{Rhizomatic layers of human nature and culture in discursively determined languages}

\subsection{On the notion of rhizome in nature and culture}

To recapitulate the whole survey of singular views of discussed authors, Deleuze and Guattari, with reference to the original definition of the term, we have specified the notion of rhizome as a conflation, or a set of binary relations, formed by multiplicity of interconnected points, or positions, in short, as a network of interrelated features; whereas the notion of feature means both a prominent or conspicuous part or characteristic of a perceivable object.

The concept of the rhizome as developed by Deleuze and Guattari in A Thousand Plateaus:

Let us summarize the principal characteristics of a rhizome: unlike trees or their roots, the rhizome connects any point to any other point, and its traits are not necessarily linked to traits of the same nature; it brings into play very different regimes of signs, and even nonsign states. The rhizome is reducible to neither the One or the multiple. It is not the One that becomes Two or even directly three, four, five etc. It is not a multiple derived from the one, or to which one is added $(n+1)$. It is comprised not of units but of dimensions, or rather directions in motion. It has neither beginning nor end, but always a middle (milieu) from which it grows and which it overspills. It constitutes linear multiplicities with $\mathrm{n}$ dimensions having neither subject nor object, which can be laid out on a plane of consistency, and from which the one is always subtracted $(n-1)$. When a multiplicity of this kind changes dimension, it necessarily changes in nature as well, undergoes a metamorphosis. Unlike a structure, which is defined by a set of points and positions, the rhizome is made only of lines; lines of segmentarity and stratification as its dimensions, and the line of flight or deterritorialization as the maximum dimension after which the multiplicity undergoes metamorphosis, changes in nature. These lines, or lineaments, should not be confused with lineages of the arborescent type, which are merely 
localizable linkages between points and positions. Unlike the tree, the rhizome is not the object of reproduction: neither external reproduction as image-tree nor internal reproduction as tree-structure. The rhizome is an antigenealogy. It is a short-term memory, or antimemory. The rhizome operates by variation, expansion, conquest, capture, offshoots. Unlike the graphic arts, drawing, or photography, unlike tracings, the rhizome pertains to a map that must be produced, constructed, a map that is always detachable, connectable, reversible, modifiable, and has multiple entryways and exits and its own lines of flight. In contrast to centered (even polycentric) systems with hierarchical modes of communication and preestablished paths, the rhizome is an acentered, nonhierarchical, nonsignifying system without a General and without an organizing memory or central automaton, defined solely by a circulation of states. (Deleuze and Guattari, A Thousand Plateaus, 1987: 21)

\subsection{Discursive manifestations of enunciative assemblages}

In this part, the term assemblage will be specified from an interdisciplinary perspective in the light of discursivism. Special attention then will be paid to the formation of discursive assemblages in the lifeworld of human subjects as participants of social communication.

Since languages manifest themselves in individual and collective forms of existence as sets of extraorganismic and intraorganismic properties of their speakers and learners they should be viewed from an evolutionist perspective according to their becoming in discursively determined domains of human life-worlds. These linguistic properties of humans are transgenerationally transmitted through epigenetic inheritance of inborn speech faculties of individuals and through cultural tradition of conventionally established verbal signs of social groupings.

In view of the enunciative formation of discursive assemblages in the lifeworld of human subjects as participants of social communication, primary attention should be devoted to semiotic codes and processes that link communicating individuals, taking part in group interactions as observable persons and inferable subjects, into interpersonal and intersubjective collectivities when they create and interpret the inferable meanings which are embodied in material bearers forming the nonverbal or verbal means and modes of human understanding.

\subsection{Language as a discursively becoming phenomenon}

Since languages manifest themselves in individual and collective forms of existence as sets of extraorganismic and intraorganismic properties of their speakers and learners they should be viewed from an evolutionist perspective according to their becoming in discursively determined domains of human life-worlds. These linguistic 
properties of humans are transgenerationally transmitted through epigenetic inheritance of inborn speech faculties of individuals and through cultural tradition of conventionally established verbal signs of social groupings.

Discourse in a more general sense refers to the relational properties of meaningbearers or meaning-processing activities determined by the social roles of communication participants and culture. Linguists and theoreticians of literature, refer the term discourse to socially and culturally determined properties of the types of texts or text-processing activities characterizing the domains of language use in human communication.

Seen, however, from the perspective of cultural and communicational sciences, discourse is specified in terms of semiotic codes and processes that link individual communicating selves, taking part in group interactions as observable persons and inferable subjects, into interpersonal and intersubjective collectivities when they create and interpret the inferable meanings, which are embodied in material bearers forming the nonverbal or verbal means and modes of human understanding.

Correspondingly, semiotic objects are regarded as the realization of language and culture in various domains of human communication, determined by the functional circles, interest spheres, or thematic preferences of people. Thus, on account of various forms of interactions, the communicational collectivities might be examined within the scope of discursive communities in relation to their constitutive elements as parts of communicational systems, individuals playing certain roles of participants in group communication, nonverbal and verbal means, channels and communicational settings.

In the domain of communicational sciences, it is important to consider a distinction between two kinds of linguistic and discursive groupings, namely linguistic collectivities and linguistic communities, and discursive collectivities and discursive communities. The boundaries of linguistic communities are determined by the use of one and the same language. Discursive communities, however, may exist even if communication participants use different varieties of the same language or even different languages functioning as mutually translatable for the tasks of communicating selves.

Semiotic properties of communicating individuals participating in discursive communities are changeable, depending on biological, psychical, social, cultural, and other ecological conditionings, which co-determine the modes of their functioning and the direction of their development. Because the discursive communities of a lower order are situated within the communities of a higher order, the autonomy principle refers here to the self-government of a small-group, applying its own laws, and functioning within the larger structures of a particular discursive community.

When the theorists of linguistics state that a determined language and a determined culture have autonomized themselves by establishing a unified system of meaning-bearers, they mean that it is only a relative autonomy. While acquiring 
a state of autonomy, a determined language and a determined culture, or rather their standard varieties, as opposed to sublanguages and subcultures, become independent from their individual members as shared means of (inter)lingual and (inter)cultural communication.

What has been recognized and shared as a standard state in a determined language or in a determined culture is imposed upon the members of linguistic or cultural communities by virtue of social sanctions. The pressure of society expressed, for instance, in rejection and acceptance, punishment and reward, or stigma and charisma, makes individual participants in communication adjust themselves to common rules without being authorized to introduce any changes in the collective character of the semiotic system formed by conventions of discursive communities.

The factor of relativity explains the occurrence of multilingualism and multiculturalism contributing to the differentiation of linguistic and cultural communities because particular languages and cultures are subjected, in their genesis and functioning, to collective customs and conventions. It depends upon the agreement of individuals and communities, situated on various societal strata, who contribute to the development of a shared means of signification and communication in the domains of human life proportionally to the degree of their standardization and codification.

Language and culture as communicational systems must be detached from individuals, in order to provide patterns of standard realizations, which have to be followed by descendants of those participants in linguistic or interlingual and cultural or intercultural communication, who have given rise to its origins and development. The fact that a determined foreign language or a determined culture can become the property of many discursive communities, speaks also in favor of the idea of separating languages and cultures from individuals and social groups.

In determining the autonomous status of language and culture as humancentered discourses, the most important problem lies in the selection of an appropriate perspective concerning their existence modes. On account of concrete and mental, static and dynamic, substantial and relational manifestations, the semiotics of language and culture may be subsumed under at least one of the six existence modes of discourses:

(1) Discourses manifest themselves in collectively accepted patterns of sensible meaning-bearers which are transmitted by source meaning-creators and received by target meaning-utilizers as the non-verbal and verbal means of intersubjective signification and inter-personal communication;

(2) Discourses sustain themselves in the individual consciousness of source meaning-creators and target meaning-utilizers as the mental equivalents of sensible meaning-bearers, being processed and interpreted as nonverbal and verbal means of intersubjective signification and interpersonal communication; 
(3) Discourses recur in the concrete sign-transmitting and sign-receiving activities of communicating persons, who possess physiological endowments for the production and reception of sensible meaning-bearers as the significative means of interpersonal communication;

(4) Discourses endure in the mental sign-processing and sign-interpreting activities of communicating persons, who possess communicational abilities which allows them to create and recognize sensible meaning-bearers as significative means of interpersonal communication being distinguishable from each other, formally correct, semantically true and pragmatically adjusted to respective contexts and situations;

(5) Discourses are deducible from the socially abstracted networks of the relational values of significative means which are externalized by individual communicators in their concrete sign-transmitting and sign-receiving activities;

(6) Discourses are assumable from networks of associations between the mental equivalents of significative means and their relational values which are internalized by individual communicators in their sign-processing and signinterpreting activities.

In fact, all the enumerated six existence modes of language and culture - in the products of nonverbal and verbal meaning-creation and meaning-utilization, in the processes of sign-transmission and sign-reception, in the processing and interpreting of nonverbal and verbal products as meaning-bearers, in the relational values of nonverbal and verbal products being realized in communicative performance and memorized through associations in communicative competence - constitute extraorganismic and intraorganismic properties of communicating selves as observable persons and inferable subjects

In opposition to communicative performance, communicative competence or networks of associations, which depend upon the physiological and mental capabilities of individual communicators, only the sets of externalized patterns of nonverbal and verbal products, as well as their relational properties, become independent from the will of particular members of determined collectivities when they function as a means of social communication.

But in the real world, language and culture, as properties of collectivity, do not constitute sets of observable data; they may be only imagined as consisting of the means and contents of interpersonal communication and intersubjective signification that are typified from observable changes in individuals when they are engaged in communicating activities.

What can concretely be singled out are no more than referential behaviors of communicators, and their interpretational practices have to be mentally inferred from the shared knowledge of communication participants. Thus, in the physical dimension, communicating selves are linked with each other as persons through 
sensible meaning-bearers carried out in their sending and receiving activities. In the logical dimension, intersubjective links come into being through the mutual understanding of people when the communication participants negotiate and confirm the extrinsic meaning of nonverbal and verbal means through interpretative practices and referential behavior on the basis of internally concluded commonalities of experience or knowledge about the same domain of reference.

Considering the role of semiotic means in the formation of discursive communities, on the basis of observable and inferable similarities in the referential behavior of human beings and their interpretational activities, one can, in consequence, subsume language and culture under two additional existence modes of discourse, where:

(7) Discourses unite the communicating selves into concretely observable, dynamic interpersonal groupings that become realized between members of discursive communities when they produce, emit, perceive and receive sensible meaning-bearers through a respective physical channel;

(8) Discourses can be deduced from the intersubjective groupings that arise between members of discursive communities when they understand or interpret received meaning-bearers in the same way, referring them to the common extrasemiotic reality known to each communicating individual separately.

In keeping with the assumption that there are also interorganismic links due to not only linguistic faculties but also cultural faculties inherited genetically, according to the ascertainments of biologically and anthropologically inclined semioticians, one may be entitled to assume that discourses exists also in the generational memory of human organisms in the form of mental memes or biosemiotic texts (cf. Dawkins' The Extended Phenotype and The Selfish Gene), Dennett's Consciousness Explained; Darwin's Dangerous Idea; and Kinds of Minds), Blackmore "Imitation and the Definition of a Meme" and The Meme Machine, with special reference to Kull's "Copy Versus Translate, Meme Versus Sign" and "Organisms Can Be Proud to Have Been Their Own Designers").

As far as this viewpoint is concerned:

(9) Discourses are possible due to an innate semiotic faculty localized in genetically specialized neuronal centers of human brains to communicate by using both nonverbal and verbal means of signification through the implementation of physiological techniques based on five main senses, as sound, sight, touch, smell, and taste.

(10) Discourses have emerged as a result of evolutionary changes of animal organisms adapting to their natural and artificial surroundings through the extension of their communicational abilities preexisting in their genetic memory as a set of primitive and more developed nonverbal and verbal means. 
It could be assumed that a participant of social communication as such must be able to simultaneously and interchangeably function in various discursive environments. While paraphrasing the metaphor of polyglotism applied to culture, one could finally state that the communicating individual as a "cultural polyglot" must be able to cope with texts coming from different cultures, i.e., he/she must know how to communicate in and understand a "multiplicity of cultural languages". Hence, he/she must be described as possessing so-called intercultural competence.

To conclude, the rhizomatic layers of discourses may be found in the enunciative aptitudes of human organisms inherited generationally through genetic codes of nature and transmitted through semiotic codes of culture. Such layers of biological and anthropological rhizomes might have developed genetic memory due to the cultural evolution of languages.

\section{Appreciating the rhizome-oriented conception of language change}

The evolution of languages and changes in languages were discussed in historical linguistics from the perspectives of different theories, such as, for example, genealogical tree theory, wave theory, stratal theory, cultural transfers and linguistic interferences, the metaphor of roofing languages in contact situations. Against their background, one might pose a question: "What is new and productive in the rhizomatic conception of language change?"

\subsection{The genealogical tree theory}

The so-called theory of genealogical tree of languages dealing with the kinship of Germanic and Indo-European languages was elaborated in August Schleicher's Zur vergleichenden Sprachgeschichte and Die Sprachen Europas in systematischer Übersicht). Explaining the grounds of divergence occurring between cognate languages which are genetically related, it made "use of a metaphor comparing languages to people in a biological family tree, or in a subsequent modification, to species in a phylogenetic tree of evolutionary taxonomy".

\subsection{The wave theory of language change}

And the second one, the so-called "wave theory" (German Wellentheorie) was presented by Johannes Schmidt in his work Die Verwandschaftsverhältnisse der indogermanischen Sprachen), explaining the convergence between remote languages. The wave theory presented "a model of language change in which a new 
language feature or a new combination of language features spreads from a central region of origin in continuously weakening concentric circles, similar to the waves created when a stone is thrown into a body of water".

\subsection{The stratal theory of language evolution}

The term substrate (cf. Lat. stratum 'a cover', 'a surface') was applied, at first, by Graziado Isaia Ascoli (1829-1907), in "Lettere glottologiche", Rivista di filologia e d'Istruzione Classica X, 1881-1882, to explain the changes, which took place in the Latin language spoken in various parts of the Roman Empire. It was accepted in linguistics with the sense: "an original language, upon which the language of invading peoples was superposed" (cf. also Ascoli. Una lettera glottologica; "Del posto che spetta al ligure nel sistema dei dialetti italiani"; and Due recenti lettere glottologiche e una poscritta nuova).

The name superstrate used in the sciences of language has been referred to the language of peoples invading a given territory. It was proposed by Walter von Wartburg (1888-1971) in his lecture („Die Ursache des Auseinanderfallens der Galloromania in zwei Sprachgebiete: Französisch und Provenzalisch") on the cause of the split of Galloromania into two language territories: French and Provençal, delivered at the session of the Saxon Academy of Sciences on May 18, 1932 in Leipzig. The term adstrate in turn, the use of which was initiated (in the same year) by Marius François Valkhoff (1905-1980) in his work of 1932 Latijn, Romaans, Roemeens, pertains to the acculturation of elements by a given language from a foreign one.

\subsection{Cultural transfers and linguistic interferences}

Cultural transfers and linguistic interferences occurring in language contact situations. The notification about phenomenon of verbal interference is a heritage of Uriel Weinreich's work of 1953, entitled as Languages in Contact. It was Robert Lado (Linguistics Across Cultures) who popularized since the year 1957 the notion of interference in the context of applied linguistics. While cultural transfers are outcomes of collective intercourses and borrowings, interferences have a solipsistic character, as far as they occur in mental spaces of individuals.

Linguistic interferences occurring in the mind of second-language learners are based on the reduction of image schemata, composed of concepts and sound patterns, to their equivalents from the first language previously acquired in a natural way. In short, interference can be described as an influence of the first-language patterns upon the patterns which are processed mentally and physiologically in the second language. 
Linguistic interferences may be considered in terms of positive or negative transfers. The latter is the source of errors in the acquisition of a foreign language. However, verbal interference takes place not in the system of a language but in the text-processing activities of communicating individuals who transfer mental patterns of meaning-carriers and their interpretations as meaning-bearers from the competence of one language to the performance of another, from the discursive patterns of one language to the discursive practices of another one.

\subsection{The metaphor of roofing languages in contact situations}

Another term for interrelationships between languages and their varieties was the metaphor of "roof". It was a German sociologist of language, Heinz Kloss (1904-1984) who utilized in his work Die Entwicklung neuer germanischen Kultursprachen seit 1800 the roof-related metaphors, according to which certain languages or dialects can cover other languages or dialects and certain others appear in the role of being covered (cf. Kloss, 20-22).

Kloss distinguished between: (1) "hedged" (Germ. gehegt) or "roofed" dialects (ïberdacht) and (2) "wild" dialects (wild), which should be recognized as "not-roofed" (dachlos). Cultivated languages develop within the borders of a hedge in the garden (im Gehege) determined by a given written language. Their bearers use a written variety of cultural languages as a superordinate language in relation to given dialects.

Wild dialects are deprived of this cultivating influence of a cultural language closely related to them by birth. Their users utilize at the same time a written language being to a lesser degree cognate or totally non-cognate with dialects they speak in the everyday communication.

Non-roofed means exchanged in verbal contacts tend to accept foreign borrowings, or spontaneous innovations of individual character. They become less and less similar to the written language being related from a linguistic point of view, including also its further varieties.

\section{Concluding remarks regarding novelties in the rhizomatic view of language change}

Reassuming, against the background of various theories of language evolutions, one can undoubtedly recognize an added value in the conception of the rhizomatic development of language as an assemblage of enunciation. From such a viewpoint, the changeability and variability of languages may be appreciated as depending upon the differentiation of humankind in phylogenesis and ontogenesis and the evolution of human lifeworld in natural and cultural dimensions. 


\section{References}

Ascoli, G.I. 1886. Due recenti lettere glottologiche e una poscritta nuova. Roma: E. Loescher.

Ascoli, G.I. 1881. Una lettera glottologica. Torino: E. Loescher. ("Lettere glottologiche". Revista di Filologia e d'Istruzione Classica X (1881-1882). 1-71).

Blackmore, S.J. 1998. "Imitation and the definition of a meme". Journal of Memetics - Evolutionary Models of Information Transmission 2.2. 159-170.

Blackmore, S.J. 1999. The meme machine. Oxford, UK: Oxford University Press.

Bühler, K. 1934/1965. Sprachtheorie. Die Darstellungsfunktion der Sprache. Zweite Auflage (Second edition). Stuttgart: Gustav Fischer Verlag, 1965 / Jena: Gustav Fischer Verlag, 1934.

Dawkins, R. 1982. The extended phenotype. Oxford, UK: Oxford University Press.

Dawkins, R. 2006. The selfish gene. $30^{\text {th }}$ Anniversary edition. Oxford, UK: Oxford University Press.

Dawkins, R. 1989/1976. The selfish gene. New edition. Oxford, UK: Oxford University Press.

Deleuze, G. and C. Parnet. 2002/1987. Dialogues II. Trans. by Tomlinson, H. and B. Habberjam. London: The Athlone Press. / New York: Columbia University Press.

Deleuze, G. and F. Guattari. 2005/1987. A Thousand Plateaus. Trans. by Massumi, B. Minneapolis, MN: University of Minnesota Press.

Deleuze, G. and F. Guattari. 1976. Rhizome. Paris: Les Éditions de Minuit.

Dennett, D. 1991. Consciousness explained. Boston, MA: Little, Brown and Co.

Dennett, D. 1995. Darwin's dangerous idea: evolution and the meanings of life. New York, NY: Simon and Schuster.

Dennett, D. 1996. Kinds of minds: toward an understanding of consciousness. New York, NY: Basic Books.

Hauser, M.D., Chomsky, N.A. and W.T. Fitch. 2002. "The faculty of language: what is it, who has it, and how did it evolve". Science 298.5598. 1569-1579.

Kloss, H. 1978. Die Entwicklung neuer germanischen Kultursprachen seit 1800. Zweite Auflage. Düsseldorf: Schwann.

Kull, K. 2000. "Copy versus translate, meme versus sign: development of biological textuality". European Journal for Semiotic Studies 12.1. 101-120.

Kull, K. 2000. "Organisms can be proud to have been their own designers". Cybernetics and Human Knowing 7.1. 44-55.

Lado, R. 1957. Linguistics across cultures. Ann Arbor, MI: University of Michigan Press.

Saussure, F. de. 1922. Cours de linguistique générale. Publié par Charles Bally et Albert Sechehaye. Avec la collaboration de Albert Riedlinger. Deuxième édition. Paris: Payot.

Schleicher, A. 1850. Linguistische Untersuchungen. 2. Teil: Die Sprachen Europas in systematischer Übersicht. Bonn: H.B. König.

Schleicher, A. 1848. Sprachvergleichende Untersuchungen. Zur vergleichenden Sprachgeschichte. Bonn: H.B. König.

Schmidt, J. 1872. Die Verwandtschaftsverhältnisse der indogermanischen Sprachen. Weimar: H. Böhlau.

Valkhoff, M. 1932. Latijn, Romaans, Roemeens. Amersfoort, UT: Valkhoff and Co.

Wartburg, W. von. 1932. „Die Ursache des Auseinanderfallens der Galloromania in zwei Sprachgebiete: Französisch und Provenzalisch. Vortrag gehalten in der Sitzung der Philologisch-Historischen Klasse der Sächsischen Akademie der Wissenschaften zu Leipzig vom 18. Mai 1932“. Forschungen und Fortschritte 8.21. 268-269.

Wąsik, Z. 2003. Epistemological perspectives on linguistic semiotics. Frankfurt am Main: Peter Lang.

Wąsik, Z. 2016. From grammar to discourse: towards a solipsistic paradigm of semiotics. Poznań: Adam Mickiewicz University Press. 
Weinreich, U. 1974. Languages in contact. Findings and problems. The Hague/Paris: Mouton.

Whorf, B.L. 1956. Language, thought, and reality. Selected writings of Benjamin Lee Whorf. Cambridge, MA: The Massachusetts Institute of Technology Press.

Wierzbicka, A. 1980. Lingua mentalis: the semantics of natural language. Sydney/New York, NY: Academic Press.

Wierzbicka, A. 1972. Semantic primitives. Frankfurt am Main: Athenäum.

Yngve, V.H. 1986. From grammar to science. New foundations for general linguistics. Amsterdam: John Benjamins.

Zawadowski, L. 1966. Lingwistyczna teoria języka. Warszawa: Państwowe Wydawnictwo Naukowe. 